\title{
DESENVOLVIMENTO DO DIREITO INTERNACIONAL NA CONCEPÇÃO DE CORNELIUS VAN BYNKERSHOEK
}

DEVELOPMENT OF THE INTERNATIONAL LAW ACCORDING TO CORNELIUS BYNKERSHOEK

Paulo Borba Casella*

\begin{abstract}
Resumo:
Cornelius van Bynkershoek (1673-1743) se inscreve como marco no desenvolvimento do Direito Internacional, dentre os autores mais relevantes, do século XVIII. Este internacionalista foi importante pelo foco pragmático dado à prática dos estados, como elemento determinante da formação e da consolidação de normas internacionais, mas curiosamente muito menos freqüentemente citado que outros internacionalistas. Este artigo analisa a especificidade e a atualidade da contribuição de Bynkershoek e aponta o seu lugar, ao lado de Grócio, e dos precursores da disciplina.

Palavras-Chave: Direito Internacional. História do Direito Internacional. Cornélio van Bynkershoek (1673-1743). Contribuição de Bynkershoek para o Direito Internacional.
\end{abstract}

\begin{abstract}
:
Cornelius van Bynkershoek (1673-1743) stands out as a landmark in the development of international law, among the most relevant authors of the XVIIIth. Century. This international legal scholar was significant for the pragmatic approach adopted, focusing on state practice as a leading element for the formation and the consolidation of international legal rules, but strangely enough is much less frequently quoted than other internationalists. This article focuses on the specific and timely contribution of Bynkershoek and points the place he deserves, besides Grotius and the forerunners of international law.
\end{abstract}

Keywords: International Law. History of international Law. Cornelius van Bynkershoek (1673-1743). Contribution of Bynkershoek to the development of International Law.

Desde o início do Direito Internacional, autores como Hugo Grócio utilizam precedentes, bíblicos, desde a história antiga, grega e romana, para estabelecer normas, de Direito Internacional. Cornelius van Bynkershoek utilizará extensamente referências à prática do seu tempo. Da mesma forma, hoje, utilizamos precedentes julgados e pareceres prolatados pela Corte permanente de justiça internacional e Corte Internacional de Justiça, ou passagens extraídas de laudos arbitrais internacionais.

\footnotetext{
Professor Titular de Direito Internacional Público e Chefe do Departamento de Direito Internacional e Comparado da Faculdade de Direito da Universidade de São Paulo. Membro do Conselho Editorial da Revista da Faculdade de Direito da Universidade de São Paulo.
} 
A contribuição de Cornelius van Bynkershoek (1673-1743) será a de enfatizar a visão pragmática e concreta do direito entre Estados e das formas de exercício e regulação das relações entre estados, reguladas pelo Direito Internacional. O pragmatismo, construído a partir da prática.

São incontornáveis, após menções a Vitória e Suarez, a figura de Grócio, ${ }^{1}$ sem esquecer autores como Gentili, Zouch, Pufendorf, Wolff, ${ }^{2}$ Bynkershoek, ${ }^{3}$ Burlamaqui, Vattel $^{4}$ e Von Martens, ${ }^{5}$ cujas concepções permanecem basilares para o estudo e a compreensão do Direito Internacional, como os fundadores (founding fathers) deste. ${ }^{6}$ Muito presentes e atuais, quer diretamente, por estes legadas, quer por meio de autores subseqüentes. ${ }^{7}$

1 Peter Haggenmacher, em seu "Le droit de la guerre et de la paix de Grotius" (HAGGENMACHER, Peter. Le droit international. Archives de Philosophie du Droit, Paris, v. 32, Sirey, p. 47-58, 1987), opina no sentido de em lugar de se atribuir a Grócio a concepção do Direito Internacional como todo, seria este o autor da síntese última, dentre as correntes de pensamento, que compunham a doutrina da guerra justa, que se vê por este transformada em teoria geral da solução pelas armas do conjunto das controvérsias que fogem das vias judiciais instituídas entre cidadãos, pelos poderes públicos.

2 OLIVE, L. Wolff. In: Les fondateurs du droit international: leurs oeuvres, leurs doctrines. Avec une introduction de Antoine Pillet. Paris: V. Giard \& E. Brière, 1904. p. 447-479).

3 DELPECH, J. Bynkershoek. In: PILLET, A. Les fondateurs du droit international public: leurs oeuvres, leurs doctrines. Paris: V. Giard \& E. Brière, 1904. p. 385-446, cit. p. 446): Ce ne serait point une remarque nouvelle: à son heure, et dans son domaine, par sa méthode, sa science et ses procédés, Bynkershoek fut, incontestablement, un de ces auteurs auxquels survivent leurs écrits et dont on dit, à juste titre, dans tous les ordres de littérature, que, sans leurs oeuvres, la science serait moins riche et eût compté, pour ses destinées, une précieuse contribution de moins.

4 MUIR-WATT, Horatia. Droit naturel et souveraineté de l'état dans la doctrine de Vattel. Le droit international Archives de philosophie du droit, v. 32, Paris: Sirey, 1987, p. 71-83, ressalta não ser adequado imputar a VATTEL o declínio da aceitação do direito natural como fundamento do direito das gentes, mas este somente teria trazido precisões ulteriores a doutrina já em gestação junto a seus predecessores da escola do direito da natureza e das gentes.

5 H. BAILBY, Georges-Frédéric De MARTENS (in Les fondateurs du droit international public: leurs oeuvres, leurs doctrines avec une introduction de A. PILLET, Paris: V. Giard \& E. Brière, 1904, p. 603-676).

6 Antoine PILLET (coord.), Les fondateurs du droit international: leurs ouevres, leurs doctrines, (Paris: V. Giard \& E. Brière, 1904, avec une introduction de Antoine PILLET, p. v-xxxi, cit. p. xxv-xxvi), ressalta (La raison d'état, qui est la force habillée d'un mot pompeux, prime tout. Peut-être dans une inssurection la justice des griefs des rebelles aidera-t-elle dans une faible mesure à leur succès en facilitant la reconnaissance de leur parti: c'est là, crois-je le seul effet juridique que puisse produire de nos jours cette distinction fameuse. Tout le reste n'est que cendres et poussière. / Ne craignons pas cependant de fouiller dans cette cendre; elle récouvre un feu qui n'est pas près de s'éteindre. (...) La doctrine ancienne ne supprime pas directement la guerre, elle cherche seulement à faire pencher la balance du côté de la justice; la tendance moderne, plus audacieuse, ne veut rien moins que substituer à la guerre la procédure arbitrale. Cela s'appelle vouloir changer la face du monde. À la vérité, à toutes les époques des projets semblables ont été formés. Mais au temps de l'abbé de SAINT-PIERRE ou de KANT ils restaient confinés dans le domaine de la spéculation philosophique; ils semblent être tombés de nos jours dans celui de l'étourderie.

7 Dos quais alguns são correntemente mencionados, e a seguir, como 'fundadores' ou 'clássicos' do Direito Internacional, por referências nos capítulos seguintes, individualmente, em relação a colocações específicas. 
Bynkershoek traz visão mais pragmática e concreta do direito entre estados e das formas de exercício e regulação das relações entre Estados, reguladas pelo Direito Internacional. O contexto já teria, contudo, passado por ulteriores desenvolvimentos.

Cornelius van Bynkershoek ${ }^{8}$ concebe o Direito das gentes como direito interestatal, fundamenta geralmente suas posições no costume das nações, no seu tempo, ${ }^{9}$ e no Direito Romano, mais que no Direito Natural. Invoca, igualmente, os ditames da justa razão (recta ratio) como fonte, mas esta surge como princípio quando falta ou seja incerto o costume, e se vincula basicamente ao Direito Romano.

Foi Bynkershoek quem cristalizou a formulação a respeito do mar territorial $^{10}$ que permaneceu válida até que se alcançasse a codificação do mar territorial ${ }^{11}$ (na Convenção de Genebra, de 1958) e da extensão deste (na Convenção das Nações Unidas sobre direito do mar, de 1982): o oceano não pode cair sob domínio de nenhum estado, por não ser suscetível de apropriação; se o alto-mar não pode ser reclamado por nenhum estado, a faixa de mar próxima da costa, pode ser reclamada pelo estado costeiro, até onde este possa exercer controle ou comando, o que, segundo Bynkershoek seria o equivalente ao alcance de tiro de canhão (o que faria, ressalta Truyol Y Serra, ${ }^{12}$ variar a extensão do mar territorial conforme a técnica militar), mas foi aceito como critério válido durante mais de duzentos anos.

A grande questão tática e estratégica, ${ }^{13}$ passou a ter regulação que a transforma em norma de Direito Internacional positivo. ${ }^{14}$ Além da extensão do mar territorial foram,

8 J. DELPECH, Bynkershoek (1673-1743) (in Les fondateurs du droit international public: leurs oeuvres, leurs doctrines «avec une introduction de» A. PILLET, Paris: V. Giard \& E. Brière, 1904, p. 385-446).

9 TRUYOL Y SERRA, A. Histoire du droit international public. Paris : Economica, 1995. p. 84-85: "Il se réfère également aux dispositions internes des États-généraux des Provinces-Unies, et les précédents sont pris de préférence dans le passé récent. L'arrière-fond judiciaire se révèle dans la logique du raisonnement, la lucidité de l'approche et la vigueur de l'expression, non exempte de brusquerie".

${ }^{10}$ BYNKERSHOEK, Cornelius van. De dominio maris dissertatio (1702) partindo de análise dos fatos, conclui, como Grócio, um século antes, no Mare liberum, pela liberdade da navegação dos oceanos.

${ }^{11}$ CONFORTI, Benedetto. Il regime giuridico dei mari: contributo alla ricostruzione dei principi generali. Napoli : Eugenio Jovene, 1957, estuda a matéria em contexto anterior às Convenções de Genebra de 1958.

${ }^{12}$ Histoire du droit international public (op. cit., 1995, loc. cit.) : "Bynkershoek a consacré une attention particulière à la neutralité, notamment sur mer. Il interprète les décrets du gouvernement des Provinces-Unies dans le sens de l'effectivité du blocus et de la légitimité de la prise du navire et de la cargaison en cas de tentative de rupture du blocus."

${ }^{13}$ PADFIELD, Peter. Maritime supremacy and the opening of the Western mind: naval campaigns that shaped the modern world 1588-1782. Londres: Random House, (C) 1999, publ. 2000.

${ }^{14}$ Prosper Weil analisa a extensão e relevância dos progressos alcançados no seu Perspectives du droit de la délimitation maritime. Paris: Pédone, 1988. 
igualmente consolidados conceitos como os de zona econômica exclusiva ${ }^{15}$ e de plataforma continental. ${ }^{16}$

Bynkershoek, com seu De foro legatorum foi, ainda, o responsável pela regulamentação da imunidade dos agentes diplomáticos e dos soberanos, ${ }^{17}$ partindo de caso concreto. ${ }^{18}$ Em mais esta matéria, foi situação concreta a norteadora da manifestação. ${ }^{19}$ Bynkershoek basicamente estipulou orientação para os consulentes em consistência com a linha adotada em codificações posteriores do assunto.

A matéria viria a ser objeto das bem-sucedidas codificações de Viena, na segunda metade do século $\mathrm{XX}$, com destaque para a Convenção sobre relações diplomáticas, 1961, sobre relações consulares, de 1963, sobre direito dos tratados, de 1969, cumpre importante papel, apontado por G. E. do Nascimento e Silva. ${ }^{20}$ Assim como nas Convenções de Viena em matéria de tratados, feitas nos anos seguintes, abordando: direito dos tratados (1969), representação do Estado em suas relações com organizações internacionais de vocação universal (1975), sucessão de estados em matéria de tratados (1978), sucessão de estados em matéria de bens, arquivos e divididas de Estado (1983),

15 ORREGO-VICUÑA, Francisco. La zona económica exclusiva: regimen y naturaleza juridica en el derecho internacional. Santiago: Edtrl. Jurídica de Chile, 1991, GARRE-COPELLO, Beltrer. La zona económica exclusiva. Montevideo: Univ. de la República / Dir. Gral. de Extension Univ., 1987.

16 V. RANGEL, Vicente Marotta. A experiência da Conferência da ONU e a Convenção sobre direito do mar. In: NAZO, Georgette Nacarato (Coord.). Questões importantes referentes ao mar. São Paulo : Soamar Sociedade dos Amigos da Marinha, 1996. p. 11-18 et al.).

17 BYNKERSHOEK, Cornelius van. De foro legatorum singularis. Leyden, 1721.

18 TRUYOL Y SERRA, Antonio. Histoire du droit international public. Paris: Economica, 1995. p. 85: "Le cas qui est à l'origine de la monographie touchait à l'immunité de la juridiction civile. Le comte de Flohz, ministre du duc de Holstein près des États-généraux des Provinces-Unies avait été décrété de saisie par la Cour Suprême de la province de Hollande pour paiement d'une dette qu'il avait contractée comme négociant. Sauf exception des crimes contre la sûrété de l'État, Bynkershoek admet l'immunité de la juridiction criminelle. Quant à l'immunité de la juridiction civile, il la restreint pour les biens qui ne sont pas attachés à la personne de l'ambassadeur, de telle sorte qu'il peut sans eux exercer ses fonctions, et à plus forte raison, s'il les consacre au commerce. Par ailleurs, l'ambassadeur, expressément autorisé par son souverain, peut renoncer à l'immunité de juridiction, et le souverain territorial, avant de donner l'agrément au ministre étranger, limiter son droit à l'immunité".

19 DELPECH, J. Bynkershoek (1673-1743). Les fondateurs du droit international public: leurs oeuvres, leurs doctrines avec une introduction de A. Pillet. Paris: V. Giard \& E. Brière, 1904. p. 385-446, cit. p. 401): Le De foro legatorum fut un ouvrage de circonstance, dont Barbeyrac dit qu' 'il est le seul avantage qui soit revenu au public à l'occasion d'un négoce, le plus ruineux qui ait jamais été inventé'. Sa portée doctrinale est demeurée cependant trés grande.

20 SILVA, G. E. do Nascimento e. Convenção sobre relações diplomáticas. 3. ed. Rio de Janeiro: Forense Univ. / Fund. Alexandre de Gusmão, 1989. "prefácio"): "A obra de codificação teve importante impulso com a Carta das Nações Unidas que prevê o desenvolvimento progressivo e a codificação do Direito Internacional”. Esse trabalho da Comissão de Direito Internacional levou à "assinatura de inúmeros e importantíssimos tratados" (...) “e as diversas convenções de Viena, como as de relações diplomáticas (1961), relações consulares (1963), direito dos tratados (1969), representação dos estados em suas relações com organizações internacionais de natureza universal (1975), sucessão de estados em matéria de tratados (1978), sucessão de estados em matéria de bens, arquivos e dívidas do estado (1983) e Direito dos Tratados entre Estados e organizações internacionais ou entre organizações internacionais (1986)". 
direito dos tratados entre Estados e organizações internacionais ou entre organizações internacionais (1986).

Cornelius van Bynkershoek (1673-1743) se inscreve em contexto no qual começa a existir tradição de Direito Internacional, e este se reporta aos grandes mestres, como Grócio e Pufenddorf, mesmo quando seja para discordar de ambos. E se põe com clareza em relação ao que considera aceitável ou passível de crítica dos ensinamentos destes.

Esse encadeamento é apontado por Bynkershoek, no seu De foro legatorum (1721): ${ }^{21}$ “se a minha discussão do assunto for apta a receber aprovação, terá sido de uma vez por todas, algo que se pode seguir; se não o for, sigamos algo que seja diferente e melhor. Mas em qualquer controvérsia, que surja sobre o direito das gentes, devemos ter o cuidado de seguir os costumes das nações, e não considerar as nossas mentes como a única fonte da sabedoria. Eu sei que com base somente na razão, ora uma ora outra decisão diversa pode ser dada, com relação à questão da jurisdição sobre os embaixadores, mas também sei que prevalece a razão que o costume das nações aprovou, e esta é a posição principalmente defendida neste tratado".

Com Cornelius van Bynkershoek chega-se a visão pragmática e concreta do direito entre estados e das formas de exercício e regulação das relações entre Estados, reguladas pelo Direito Internacional. Este é concebido por Bynkershoek ${ }^{22}$ como Direito Interestatal, fundamentado no costume das nações, no seu tempo, ${ }^{23}$ e no Direito Romano, mais que no Direito Natural.

Invoca Bynkershoek os ditames da justa razão (recta ratio) como fonte, mas esta surge como princípio quando falta ou seja incerto o costume, e se vincula basicamente ao Direito Romano. Mas, no Direito Internacional, será o costume o elemento legitimador

\footnotetext{
${ }^{21}$ BYNKERSHOEK, Cornelius van. Deforo legatorum tam in causa civili quam criminali liber singularis. Leyden, 1721, a monograph on the jurisdiction over Ambassadors in both civil and criminal cases ("a photographic reproduction of the text of 1744", with an English translation by Gordon J. Laing, and an introduction by Jan de Louter, esta datada de 1922, com menção "imprimatur" 1929, The Classics of International Law, v. XXI, ed. by James B. Scott, Oxford: at the Clarendon Press / London: Geoffrey Cumberlege, 1946; "ad lectorem") e prossegue: "Quid ipse sentiam, leges, si commodum est, in hoc exiguae molis libello, si non est, heic loci non audies" - e qual seja a minha opinião lerá neste pequeno livro, se for de sua conveniência fazê-lo; e se não for, não será aqui que eu a direi.

${ }^{22}$ DELPECH, J. Bynkershoek (1673-1743). Les fondateurs du droit international public: leurs oeuvres, leurs doctrines. Avec une introduction de A. Pillet. Paris: V. Giard \& E. Brière, 1904. p. 385-446.

${ }^{23}$ TRUYOL Y SERRA, Antonio. Histoire du droit international public. Paris: Economica, 1995. p. 84-85: "Il se réfère également aux dispositions internes des États-généraux des Provinces-Unies, et les précédents sont pris de préférence dans le passé récent. L'arrière-fond judiciaire se révèle dans la logique du raisonnement, la lucidité de l'approche et la vigueur de l'expression, non exempte de brusquerie".
} 
(unde jus gentium est), como evidência da convicção de juridicidade, em relação à prática da totalidade ou da maioria das nações. ${ }^{24}$

No seu De dominio maris dissertatio (1702, segunda edição 1744) parte Bynkershoek de análise dos fatos, para concluir, como Grócio, um século antes, no Mare liberum (1608), pela liberdade da navegação dos oceanos. Deve-se a Bynkershoek a formulação a respeito do mar territorial, ${ }^{25}$ que permanece até a conceituação do mar territorial $^{26}$ (Convenção de Genebra, de 1958) e da extensão deste (Convenção das Nações Unidas sobre Direito do Mar, de 1982): o oceano não pode cair sob domínio de nenhum Estado, por não ser suscetível de apropriação; se o alto-mar não pode ser reclamado por nenhum Estado, a faixa de mar próxima da costa, pode ser reclamada pelo Estado costeiro, até onde este possa exercer controle ou comando, o que, segundo Bynkershoek seria o equivalente ao alcance de tiro de canhão (o que faria, ressalta Truyol y Serra, ${ }^{27}$ variar a extensão do mar territorial conforme a técnica militar), mas foi aceito como critério válido durante mais de duzentos anos.

\footnotetext{
${ }^{24}$ Contrariamente ao esforço de fundamentação da disciplina, engajado por Grócio, por sua vez Bynkershoek se limita a duas das fontes do direito positivo: a razão (ratio), ou a razão de ser de uma certa coisa, e o costume, como prática continuada da totalidade ou da maioria das nações, mas falha em dar clara e firme compreensão da exata relação entre estas. Normalmente põe à frente a razão (ratione praeeunte, De foro legatorum, cap. III), mas positivamente nega a força vinculante desta, se não sustentada pelo uso uniforme (unde jus gentium est, De foro legatorum, cap. VII), e freqüentemente admite que razões opostas, tanto quanto costumes comprovados, muitas vezes se equilibram. Então voltar-se-á ao direito romano, como a expressão da razão escrita (ratio scripta), a voz de quase todas as nações, que deveria ser levada em consideração por praticamente todos os juristas. Ao mesmo tempo, mostra-se perfeitamente consciente das limitações do direito romano, para responder às necessidades do tempo presente, e não hesita em por de lado as prescrições deste, quando não correspondam às exigências da realidade. Nesses casos, consulta os costumes das nações e cuidadosamente pesa fatos e ações conflitantes, para alinhar-se finalmente para o que the parece, guiado por seu intelecto vivo e direcionado pela lógica de idéias preconcebidas, para a superioridade de casos, em número e em peso.

${ }^{25}$ BYNKERSHOEK, Cornelius van. De dominio maris dissertatio (1702) (a dissertation on the sovereingty of the sea "a photographic reproduction of the text of 1744", with an English translation by Ralph van Deman MAGOFFIN, with an introduction by James Brown SCOTT, The Classics of International Law, v. XI, ed. by James B. SCOTT, New York / Oxford: University Press, 1923). No seu De dominio maris dissertatio parte Bynkershoek de análise dos fatos, para concluir, como Grócio, um século antes, no Mare liberum, pela liberdade da navegação dos oceanos.

${ }^{26}$ CONFORTI, Benedetto no seu (Il regime giuridico dei mari: contributo alla ricostruzione dei principi generali. Napoli: Eugenio Jovene, 1957) ainda estuda a matéria em contexto anterior às Convenções de Genebra de 1958.

${ }^{27}$ Histoire du droit international public (op. cit., 1995, loc. cit.): "Bynkershoek a consacré une attention particulière à la neutralité, notamment sur mer. Il interprète les décrets du gouvernement des Provinces-Unies dans le sens de l'effectivité du blocus et de la légitimité de la prise du navire et de la cargaison en cas de tentative de rupture du blocus".
} 
Grande questão tática e estratégica, ${ }^{28}$ passa a delimitação do mar territorial a ter regulação que a transforma em norma de Direito Internacional positivo, ${ }^{29}$ somente na segunda metade do século XX - tal como se esboça com a Convenção de Genebra (1958) e se completa com a Convenção das Nações Unidas para o Direito do Mar (1982), ao ponto de Prosper Weil (1988 e 1992) ${ }^{30}$ falar em conquista da delimitação marítima pelo direito. Além da extensão do mar territorial foram, igualmente consolidados conceitos como os de zona econômica exclusiva ${ }^{31}$ e de plataforma continental. ${ }^{32}$

A obra De foro legatorum (1721, segunda edição 1744) ${ }^{33}$ de Bynkershoek aborda tema clássico do Direito Internacional - "penso não haver, no campo do direito público, outra matéria mais discutida do que a que abrange as questões relativas aos embaixadores" ${ }^{34}$ - e foi responsável pela regulamentação da imunidade dos agentes diplomáticos e dos soberanos, a partir de caso concreto. ${ }^{35}$

${ }^{28}$ PADFIELD, Peter. Maritime supremacy and the opening of the Western mind: naval campaigns that shaped the modern world 1588-1782. Londres: Random House, (C) 1999, publ. 2000).

${ }^{29}$ Prosper Weil analisa a extensão e relevância dos progressos alcançados: (Perspectives du droit de la délimitation maritime. Paris: Pédone, 1988); WEIL, Prosper. Le droit international en quête de son identité: cours géneral de droit international public (RCADI, 1992, t. 237, p. 9-370).

${ }^{30}$ WEIL, Prosper. op. cit.

${ }^{31}$ ORREGO-VICUÑA, Francisco. La zona económica exclusiva: regimen y naturaleza jurídica en el derecho internacional. Santiago: Edtrl. Jurídica de Chile, 1991; GARRE-COPELLO, Beltrer. La zona económica exclusiva. Montevideo: Univ. de la República / Dir. Gral. de Extension Univ., 1987.

${ }^{32}$ RANGEL, Vicente Marotta. A experiência da Conferência da ONU e a Convenção sobre direito do mar. In: NAZO, Georgette N. (Coord.). Questões importantes referentes ao mar. de São Paulo: Soamar - Sociedade dos Amigos da Marinha, 1996. p. 11-18 et al.

${ }^{33}$ BYNKERSHOEK, Cornelius van. De foro legatorum (1721, ed. 1946).

${ }^{34}$ (Id. Ibid. "ad lectorem"): "non puto ullum juris publici argumentum plus agitatum esse, quam id, quod circa legatos versatur". Menciona, dentre os que o precederam no tratamento do tema: HOTMAN, Jean. L'Ambassadeur; BESOLD, Christoph. Dissertatio de legatis eorumque iure.

${ }^{35}$ TRUYOL Y SERRA, Antonio. Histoire du droit international public. Paris: Economica, 1995. p. 85: "Le cas qui est à l'origine de la monographie touchait à l'immunité de la juridiction civile. Le comte de Flohz, ministre du duc de Holstein près des États-généraux des Provinces-Unies avait été décrété de saisie par la Cour Suprême de la province de Hollande pour paiement d'une dette qu'il avait contractée comme négociant. Sauf exception des crimes contre la sûrété de l'État, Bynkershoek admet l'immunité de la juridiction criminelle. Quant à l'immunité de la juridiction civile, il la restreint pour les biens qui ne sont pas attachés à la personne de l'ambassadeur, de telle sorte qu'il peut sans eux exercer ses fonctions, et à plus forte raison, s'il les consacre au commerce. Par ailleurs, l'ambassadeur, expressément autorisé par son souverain, peut renoncer à l'immunité de juridiction, et le souverain territorial, avant de donner l'agrément au ministre étranger, limiter son droit à l'immunité". 
Em mais esta matéria, foi situação concreta a norteadora da manifestação. ${ }^{36}$ Bynkershoek basicamente estipulou orientação para os consulentes em consistência com a linha adotada em codificações posteriores do assunto: ${ }^{37}$

Matéria viria a ser objeto de codificações quando do Congresso de Viena (1815), com formulação, no Direito Internacional vigente, na Convenção sobre relações diplomáticas (1961), e sobre relações consulares (1963). Cumprem estas, importante papel, apontado por G. E. do Nascimento e Silva. ${ }^{38}$ Assim as Convenções de Viena, feitas nos anos seguintes : direito dos tratados (1969), representação do estado em suas relações com organizações internacionais de vocação universal (1975), sucessão de Estados em matéria de tratados (1978), sucessão de estados em matéria de bens, arquivos e dívidas de Estado (1983), direito dos tratados entre estados e organizações internacionais ou entre organizações internacionais (1986).

O tratado De foro legatorum (1721) começa pela análise das diferentes categorias de agentes diplomáticos, seus vários títulos e condições, que, contudo, não podem de modo algum influenciar as questões atribuídas ao juiz competente para julgar a causa, ${ }^{39}$ mas somente indicam a classificação do agente e a remuneração deste. A distinção entre emissários ordinários e extraordinários é igualmente irrelevante: os últimos, os mais antigos e durante muito tempo os únicos conhecidos, no Direito Internacional, enquanto os enviados permanentes seriam o resultado da moderna justaposição de Estados igualmente soberanos, e da crescente extensão das relações entre estes. Bynkershoek examina ${ }^{40}$ como o juiz competente pode ser determinado: em princípio toda jurisdição é atribuída ao poder

${ }^{36}$ DELPECH, J. Bynkershoek (1673-1743). In: Les fondateurs du droit international public: leurs oeuvres, leurs doctrines. Avec une introduction de A. Pillet. Paris: V. Giard \& E. Brière, 1904. p. 385-446, cit. p. 401): «Le De foro legatorum fut un ouvrage de circonstance, dont Barbeyrac dit qu' 'il est le seul avantage qui soit revenu au public à l'occasion d'un négoce, le plus ruineux qui ait jamais été inventé'. Sa portée doctrinale est demeurée cependant trés grande».

${ }^{37}$ BYNKERSHOEK, Cornelius van. De dominio maris dissertatio (ed. cit. 1923). Este breve tratado integra o volume das Opera minora de Bynkershoek, publicado após a morte deste, em 1744, no qual se reúnem sete tratados, do qual o último é o De foro legatorum, precedido pelo tratado De dominio maris dissertatio.

${ }^{38}$ SILVA, G. E. do Nascimento e. Convenção sobre relações diplomáticas. 3. ed. Rio de Janeiro: Forense Univ. / Fund. Alexandre de Gusmão, 1989. "prefácio"): "A obra de codificação teve importante impulso com a Carta das Nações Unidas que prevê o desenvolvimento progressivo e a codificação do Direito Internacional”. Esse trabalho da Comissão de Direito Internacional levou à "assinatura de inúmeros e importantíssimos tratados" (...) "e as diversas convenções de Viena, como as de relações diplomáticas (1961), relações consulares (1963), direito dos tratados (1969), representação dos estados em suas relações com organizações internacionais de natureza universal (1975), sucessão de estados em matéria de tratados (1978), sucessão de estados em matéria de bens, arquivos e dívidas do estado (1983) e direito dos tratados entre estados e organizações internacionais ou entre organizações internacionais (1986)".

${ }^{39}$ BYNKERSHOEK. op. cit. cap. I.

${ }^{40}$ Id. Ibid. cap. II). 
soberano (pendeat e ares a sola subjectione et, absque ea si sit, irrita est omnis jurisdictio), sem consideração da forma de governo, seja monarquia ou república. ${ }^{41}$

Jurisdição e soberania são inseparáveis. Conseqüência dessa premissa o fato de que o soberano que se encontre em estadia, voluntária ou incidentalmente, em território estrangeiro, não está sujeito à jurisdição local. ${ }^{42} \mathrm{~A}$ inocorrência de casos compele ao uso exclusivo da razão. ${ }^{43}$

Objeto central do tratado De foro legatorum, Bynkershoek trata da famosa questão da alegada santidade ou inviolabilidade dos embaixadores, ${ }^{44}$ uma das mais antigas e mais fundamentais máximas do direito das gentes. ${ }^{45} \mathrm{O}$ representante do soberano, em outro país, deve ser inatacável, e não-sujeito a qualquer constrição, pois este representa aquele que o envia, promove a paz e as relações amistosas, e mantém a tranqüilidade da sociedade humana. ${ }^{46}$

${ }^{41}$ J. de LOUTER (intr. cit., 1922, publ. 1946, p. xiii) observa que a expressão do rei como fonte de justiça (fons juris) poderia conduzir a distorções, porquanto a jurisdição deste somente se estende aos seus súditos, ou seja, aqueles nacionais ou estrangeiros, residentes no território, bem como aos bens, imóveis e móveis, que neste se encontrem.

${ }^{42}$ BYNKERSHOEK. op. cit. cap. III. Tanto quanto sejam evitados os conflitos, nada obsta o exercício do poder, inteiramente fora da jurisdição territorial. Da mesma forma, o particular, que visita outro país, não está imediatamente sujeito à jurisdição local, em matéria civil, como claramente decorre da bem conhecida doutrina jurídica do local de celebração do contrato (locus contractus). Somente quando muda seu domicílio, ou seja o centro de seus negócios e fortuna (rerum ac fortunarum sedes, cap. VIII), como, salvo raras exceções, na maioria dos países se pode fazer, põe-se este no mesmo plano dos habitantes daquele território; de outro modo, somente estará sujeito ao exercício da jurisdição penal, porque esta abrange o inteiro território, em razão da doutrina do forum criminis, e ao procedimento penal comum. A questão de saber se o soberano que incorre em obrigações financeiras ou comete crime em território estrangeiro possa ser julgado pelas cortes locais é delicada e deve ser considerada com cautela: muito pode ser dito a respeito, em ambos os sentidos, e os casos que se revestem de autoridade são raros e equívocos. Bynkershoek, seguindo o aplicável aos embaixadores, tende a conferir-lhes isenção total, mas, em casos extremos de força palpável, admite o direito de expulsão, ou mesmo de remoção violenta, mas não de prisão nem detenção.

43 BYNKERSHOEK, De foro legatorum (ed. cit., cap. IV) quanto aos bens pertencentes ao soberano o caso é diverso. Da mesma forma, os bens particulares, em determinado país, podem ser arrestados e vendidos, sob a autoridade do juiz territorialmente competente. Alguns casos, na maioria extraídos da história e da jurisprudência holandesa, provam a incerteza e a diversidade das soluções. Contudo, a escala se move rumo à jurisdição territorial, desde que, em qualquer caso, o devido respeito e consideração sejam mostrados em relação à dignidade do soberano, como diversa daquela de qualquer outro.

${ }^{44}$ BYNKERSHOEK (op. cit., ed. cit. cap. V).

45 Dentre os autores citados por Bynkershoek : o jurisconsulto francês Jacques Cujas (1520-1590), como o mais ilustre representante da escola histórica de exegese dos textos do direito latino, bem como o aqui referido Alberico Gentili, e sobretudo Hugo Grócio, como principal mestre do direito público (princeps juris publici magister).

${ }^{46}$ Qualquer ação intentada contra o embaixador é como se a ação fosse voltada contra o soberano, e portanto é mais criminosa e merece mais severa punição que a ação intentada contra um particular. Erroneamente, contudo, Grócio recorre a este princípio, como o real fundamento para a isenção dos embaixadores, em relação à jurisdição local. A citação não constitui constrição e o direito romano já admitia a inviolabilidade de determinadas classes de homens, tais como os tribunos da plebe (tribuni plebis) os quais, contudo, submete à jurisdição local. Mesmo um sacerdote, embora inviolável, pode ser citado, quando não estiver no exercício de suas funções. 
Bynkershoek faz decorrer a jurisdição sobre os legados (de foro legatorum), enquanto determinação do tribunal competente, do princípio já exposto de que o embaixador, via de regra, permanece, apesar de seu distanciamento, súdito de seu soberano e como tal sujeito às normas como ao foro de seu domicílio de origem. ${ }^{47}$

Na verdade, a razão será o único guia, para a solução da intrincada questão. Existem, na verdade, sólidos argumentos em favor da aplicação da lei local e da submissão à jurisdição local, tais como a igualdade perante a lei, em todas as coisas que não digam respeito ao exercício estrito das funções do embaixador, os múltiplos interesses dos credores nacionais e dos cidadãos, que poderiam ser atingidos ou lesados, por pessoas integrantes das legações. ${ }^{48}$

As desvantagens decorrentes da outorga de imunidades podem ser reduzidas ou evitadas, mediante criteriosa estipulação das partes contratantes, e por meio de outras garantias contra danos, asseguradas pelo Direito, e que resguardem o âmbito de exercício do poder territorial. ${ }^{49} \mathrm{~A}$ explicação e a aplicação destes princípios constituem o cerne do tratado. $^{50}$

O embaixador que personifica o seu soberano goza da mesma extraterritorialidade, não pode se submeter a qualquer outro poder e permanece livre do exercício da soberania local. ${ }^{51}$ Somente mediante acordo expresso entre as partes

\footnotetext{
47 Por não ter alterado o seu domicílio não pode, conseqüentemente, seja em questões civis ou criminais, estar sujeito à jurisdição local, nem trazido à presença do magistrado, instrumento de soberano que não é o seu. Assim, não somente se lhe permite, mas tem mesmo o dever de rejeitar a jurisdição de seu local de residência. A isto chama domum revocare, que Barbeyrac traduz como demander un renvoi. Essa conseqüência provisória é colocada sob a luz do direito romano, da autoridade de juristas qualificados, como do costume das nações. Com relação ao direito romano (em seu cap. VI) aponta a distinção entre os legati das províncias e das municipalidades, mencionados pelos juristas romanos, e os que eram sujeitos ao império romano, em relação aos embaixadores, representantes de soberanos estrangeiros. Conseqüentemente rejeita a doutrina romana da submissão destes à jurisdição local, por dívidas por eles incorridas, ou crimes cometidos, depois de terem encetado o exercício de suas funções. Contudo, homem como Gentili não hesita em identificar esses dois tipos de agentes, que pouca coisa tinham em comum, além do nome.

${ }^{48}$ Estas, em várias ocasiões, levaram os tribunais holandeses a se convencerem da aplicação de sua jurisdição. Mas, são, contudo, contrabalançados pelo interesse predominante, de que as funções dos representantes dos poderes estrangeiros permaneçam livres de quaisquer impedimentos. Suas funções exigiriam completa imunidade. Implicam muitas delicadas investigações e medidas, algumas perigosas e questionáveis, que poderiam envolver o agente em dificuldades e expô-lo a suspeita e a perseguição. Esse risco tem de ser evitado a qualquer custo. Por isso, devem ficar livres de qualquer constrangimento, que impedisse o embaixador de desempenhar as suas delicadas funções, que, segundo Bynkershoek, podem mesmo exigir ações duvidosas ou imorais, tais como fazer intrigas, pagar suborno, corromper e seduzir (prece aut pretio, vino et venere). A mais leve possibilidade de constrição limitaria a sua capacidade de ação, e diminuiria o alto valor de sua profissão.

${ }^{49}$ Desde 1651 teria sido esta a posição adotada pelo Judiciário holandês. A instabilidade foi criticada por De Wicquefort com justificado sarcasmo.

${ }^{50}$ BYNKERSHOEK. op. cit. caps. VII a XIV).

${ }^{51}$ GRÓCIO. De jure belli ac pacis (II.XVIII, parágrafos 4 a 9).
} 
interessadas pode ser afastada a aplicação dessa norma básica, e derrogação tácita não pode ser admitida. ${ }^{52}$

O único foro ao qual o embaixador pode ser submetido é o da própria jurisdição do seu soberano, que delegou o exercício da função judicial ao Poder Judiciário de seu país, habitualmente ao juiz do respectivo domicílio. A condição bastante distinta dos agentes consulares não deve, aqui, ser confundida.

Expressa a norma geral, Bynkershoek examina se podem ocorrer exceções quando ocorre ser o embaixador um súdito, seja cidadão ou habitante, do país de sua residência e domicílio de origem. ${ }^{53}$ Ao lado do desvio interessante da regra geral, de ser o embaixador súdito do soberano do qual é representante, são apontadas algumas exceções de importância reduzida e ainda menor ocorrência: ${ }^{54}$ o embaixador, nacional de terceiro estado, conservaria o seu domicílio e o vínculo com a jurisdição do foro deste.

Volta a dizer Bynkershoek que o título e a dignidade do agente não tem qualquer conseqüência sobre a sua condição jurídica, desde que a sua nomeação e o caráter de sua representação não possam ser questionados - verdade essa muitas vezes desconsiderada, no curso do século XVIII. ${ }^{55}$ Critica severamente a jurisprudência da Corte

${ }^{52}$ Opiniões de especialistas e o costume das nações afirmam essa conclusão, que De Wicquefort prova abundantemente. O Governo holandês reconheceu a adequação de tal entendimento e confirmou-lhe a validade, por meio do Edito de 9 de setembro de 1679, cuja detalhada interpretação dá mostras da sagacidade do autor, como da sutileza de seu raciocínio, cfr. J. De Louter (intr. cit. p. xvi).

53 Situação anômala, porém não vedada, no século XVII, exceto na França, e que causara grandes controvérsias na Holanda, a seu tempo, onde em 1674, um hábil oficial holandês, De Wicquefort, tinha sido nomeado embaixador do Duque de Lüneburg. Esse sujeito, criador de cizânia, causa grandes controvérsias e constrangimentos, ao publicar anonimamente documentos de estado, em conseqüência do que foi julgado e, por sentença prolatada em 20 de dezembro de 1679, condenado a prisão perpétua, e sujeito a confisco de patrimònio. Tratava-se de caso criminal, mas a comoção, causada pela ocorrência memorável, leva à ampliação do âmbito de exame da questão. Em diversos escritos e com grande vigor De Wicquefort argumenta que, na qualidade de embaixador, ao encetar o exercício de suas funções, interrompera o seu domicílio original, e teria adquirido novo domicílio, por extensão de sua nomeação, pelo soberano estrangeiro. J. De LOUTER (intr. cit., loc. cit.) pondera ser estranho não tenha Bynkershoek considerado inadmissível que a mesma pessoa fosse súdito de duas soberanias, e sujeito a ambas, desde que não colidissem os seus deveres, resultantes de suas duplas funções. Felizmente, observa De Louter, essa anomalia ficou para a história passada do direito das gentes. Ao mesmo tempo, Bynkershoek considera o domicílio original como o único correto, e objetado contra o fato de se fazer qualquer recurso a um juiz estrangeiro. Aparentemente, as fortes razões, inicialmente alegadas, em favor da completa imunidade da legação, parecem ter perdido muito de sua força. Essa opinião coincidiu com o Decreto holandês de 19 de junho de 1681. Além disso, em 1727, a República holandesa proíbe seus cidadãos de aceitarem a condição de legados de potências estrangeiras.

54 Tal como a condição dos cardeais da Igreja católica como embaixadores, à luz do Direito Canônico.

$55 \mathrm{Na}$ época a nomenclatura dos agentes diplomáticos era bastante fluida, como viria a ser no século XIX, e dependia exclusivamente dos costumes de cada corte. Embaixadores residentes eram menos freqüentes que enviados extraordinários. Agentes eram considerados como revestidos de status inferior. Um secretário de legação, embora distinto do secretário de embaixador, tinha a mesma condição e privilégios. 
holandesa e volta a afirmar a sua teoria da sujeição ao domicílio. Bynkershoek chega ao ponto de rejeitar qualquer jurisdição local, em relação à própria legação. ${ }^{56}$

A extraterritorialidade do embaixador comportaria, segundo Bynkershoek, muitas exceções. Em tais casos, pode ser citado perante a justiça local. ${ }^{57}$ Submissão voluntária é permitida, desde que não tenha sido proibida pelo soberano estrangeiro.

O exame da jurisdição penal ${ }^{58}$ é precedido pela judiciosa observação de que a criminalidade e a impunidade dos agentes diplomáticos não deve ser tratada, nem tampouco o direito de legítima defesa, em caso de ataque pessoal: o caso somente diz respeito ao juiz competente se um crime for cometido. ${ }^{59}$ Bynkershoek rejeita a submissão aos tribunais locais e considera a demissão do embaixador e a entrega deste ao seu soberano como a única medida válida e justa, exceto se se tratar de legítima defesa, que dê respaldo a desforço imediato. ${ }^{60}$

Considera ser tácita a concordância das nações com relação ao reconhecimento da imunidade dos embaixadores. Bynkershoek admite a competência de cada nação para renunciar aos privilégios e imunidades de um seu embaixador ${ }^{61}$ Alguns casos específicos podem comportar que o embaixador seja passível de julgamento em matéria civil e criminal, e possa ser condenado pelo juiz local. ${ }^{62}$

A presunção, herdada de outras eras, quanto a gozar a sede da missão, como a residência, da prerrogativa de oferecer asilo a criminosos comuns, perseguidos pela justiça, vai mais longe. ${ }^{63}$ Depois de referir e criticar abusos cometidos em Roma e em Madri, durante os séculos XV e XVI, Bynkershoek se insurge contra tal prática, que qualifica como ridícula, e pautada pela injustiça.

Depois de todo o exame da matéria, Cornelius van Bynkershoek, no capítulo final do De foro legatorum (1721), considera as opiniões de outros autores a respeito do

\footnotetext{
${ }^{56} \mathrm{O}$ consentimento do governo de origem, tal como o afirmava Grócio, somente seria aplicável em caso de punição pública ou pena capital.

${ }^{57}$ BYNKERSHOEK. op. cit. cap. XV.

58 Id. Ibid. caps. XVII a XX).

59 A habitual distinção entre crime comum e crime político não se mostra de grande valia, para esclarecer a matéria.

${ }^{60}$ A questão, contudo, é controvertida, e sólidas razões podem ser aduzidas como argumentos, em favor de ambas interpretações. Enquanto Grócio argumentara com julgamentos de especialistas e conjecturas baseadas na razoabilidade, Bynkershoek considera duvidoso o método e prefere casos, por ele chamados de exemplos, em relação a testes e opiniões, esperando assim obter resultado satisfatório.

${ }^{61}$ Dentro de certos limites, dependendo de instruções do embaixador e do consentimento tácito do governo local, poderia o embaixador, segundo Bynkershoek, exercer pessoalmente a jurisdição sobre os empregados domésticos, e puni-los, ou ao menos garantir que estes não causem, novamente, danos.

${ }^{62}$ BYNKERSHOEK (op. cit., ed. cit. cap. XXII). A possibilidade de renúncia pelo embaixador, que apele a outro juiz, que não aquele que seria competente para o julgar, segundo o direito das gentes, é objeto de consideração : estritamente proibida em casos criminais, pode comportar algumas exceções em matéria civil (cap. XXIII).

${ }^{63}$ BYNKERSHOEK (op. cit., ed. cit. cap. XXI).
} 
tema, e vale-se do ensejo para defender as suas teses e criticar as dos opositores. ${ }^{64} \mathrm{O}$ tratado breve porém completamente um tópico relevante do direito das gentes, tal como transmitido desde a Antigüidade e tratado com notável parcialidade, desde então. ${ }^{65}$

Depois de seus outros estudos, e de tempo considerável dedicado ao estudo do Direito Romano, Bynkershoek mencionava poderia passar à consideração, conforme seu propósito, às questões do Direito Público, "naqueles assuntos usualmente discutidos nas cátedras" e "assuntos tratados nas câmaras governamentais e judiciais". ${ }^{66}$

Essa contribuição está contida na obra maior de Cornelius van Bynkershoek, Quaestionum juris publici libri duo (1737), ${ }^{67}$ ao lado dos dois estudos antes referidos, cruciais para a avaliação de sua contribuição para o desenvolvimento do Direito Internacional.

As Questões de direito público se põem, não-somente como a mais extensa obra de Bynkershoek, na sua estrutura, em dois livros, de extensão mais ou menos equivalente, como a mais representativa de sua concepção do Direito Internacional. O primeiro livro trata da guerra, e o segundo de vários assuntos. O conjunto não tem o mero caráter de coletânea de estudos esparsos, originados por manifestações a respeito de eventos contemporâneos, mas reveste-se da dimensão de compilação das opiniões do Autor, sobre vasta extensão dos temas de Estudo do Direito Internacional. Para não retomar tudo o que já foi tratado pelos seus predecessores, desse modo, prefere adotar o tratamento dos temas, em capítulos selecionados, em lugar de arranjos sistemáticos.

\footnotetext{
${ }^{64}$ Pondera Jan de LOUTER (intr. cit., pp. xx-xxiv) que Bynkershoek mostra a sua superioridade, em meio ao emaranhado de noções superficiais e vulgares, mantendo mão firme e os bem fundados princípios, que foram o seu ponto de partida. Quanto ao mérito científico e contribuição específica, considera oportuna a separação entre a forma e o conteúdo e aponta o estudo dos princípios que fundamentam a argumentação, e servem de guia para as deduções e as aplicações, daí decorrentes. E conclui: "Rather keen and sagacious than profound or philosophical, he takes a foremost place in the long series of jurists who patiently and steadfastly built up the still unfinished temple of the positive law of nations. The pious commemoration of the ancestors may be a precious stimulus for the unremitting application of their progeny".

${ }^{65}$ Entende De Louter (intr. cit., pp. xx-xxi) ter ficado confinado o exame a uma subdivisão da matéria, além de não exaurir o tema, visto somente aflorar a questão da natureza e da fonte do Direito Internacional : "van Bynkershoek was an eminent jurist but no philosopher, driven by the irresistible pressure of mind and conscience to penetrate into the depth of the puzzles that envelop all human research", e o admite o próprio Bynkershoek tal forma que "Memineris etiam, me non aliter scribere, quam solent occupatissmi" - lembre-se, também, que o meu método de escrever não diverso de como o fazem os homens muito ocupados.

${ }^{66}$ C. v. BYNKERSHOEK, «Ad lectorem»: «me tunc satis dedisse Jurisprudentiae Romanae, \& animum esse, si quid in posterum molirer, transire ab bis, quae in solis fere JCtorum Cathedris aguntur, vel Auditoriis judicum tractari solent. Quare tunc fidem dedi, me, si quid vita superesset, id esse impensurum Juri Publico vel Patrio»

${ }^{67}$ BYNKERSHOEK, Cornelius van. Quaestionum júris publici libri duo, quorum primus est De rebus bellicis, secundus De rebus varii argumenti, Leyden, 1737, volume one: "the photographic reproduction of the edition of 1737", volume two: "the English translation by Tenney Frank, and an introduction by Jan de Louter" esta datada de 1922, The Classics of International Law, v. XIV, ed. by James B. Scott, Oxford : at the Clarendon Press / London : Humphrey Milford, 1930, 2 tomos, XLVI + 304 p.; XXXVIII+384+34 p.).
} 
É importante situar como Bynkershoek compreende e aplica a razão, ou bom senso, por muitos considerada, a "senhora do Direito Internacional", ${ }^{68}$ como o seu guia principal; em seguida, aponta o papel dos acordos internacionais, bem como as resoluções (edicta) e decretos (decreta) dos Estados Gerais da União dos Países Baixos, porquanto estes, embora legalmente confinados ao âmbito de aplicação do próprio país, são entretecidos de questões internacionais; em terceiro lugar, cumpre frisar o papel dos fatos e casos (exempla) tomados, de preferência, da história mais recente. Mostra Bynkershoek o cuidado que se deve ter com as opiniões dos homens: ${ }^{69}$

opiniões e os modos de agir mudam, de verdade, contudo, os eventos contemporâneos devem ser evitados, por receio de ferir os sentimentos de pessoas vivas, ou de imiscuir-se em discussões correntes. Como, contudo, são falíveis as opiniões humanas, e mutáveis, mesmo quando os membros de conselho ou tribunal sejam os mesmos, as diferenças de opinião são inevitáveis. Cada um se põe em defesa de sua convicção e, assim, numerosas referências de assim chamadas autoridades não servem para nada.

A relação de Bynkershoek com mestres como Grócio e Pufendrof é igualmente relevante seja situada. Faz exceção Bynkershoek para a relevância das opiniões destes, mas nem por isso deixa de criticá-los, quando entende que as opiniões por eles formuladas não eram adequadas.

A autoridade, derivada do uso e da prática constantes conferem peso ao que a razão pede, porquanto a razão, embora sempre a mesma, freqüentemente é ambígua e, assim, o uso, ou o costume continuado, o primeiro de todos os tiranos, decide.

O livro primeiro, em seu capítulo I, traz a fundamentação da construção que virá a seguir. Começa com a questão da definição da guerra (definitio belli, ejusque explicatio).

Considera Bynkershoek imperfeita a clássica definição de Cícero, inicialmente referida: ${ }^{70}$ 'bellum est genus decertandi per vim', tacitamente aprovada por Grócio, esta definição, quando este, por sua vez, formula ser a 'guerra o estado daqueles que lutam, com uso da força, na sua qualidade'. ${ }^{71}$ Considera, ademais, seria ainda imperfeita a definição de Gentili, 'publicorum armorum juxtam contentionem'. ${ }^{72}$

\footnotetext{
${ }^{68}$ J. De LOUTER (introdução citada, 1922, p. xii): "the mistress of international law".

69 BYNKERSHOEK, C. v. Ad lectorem.

${ }^{70}$ M. T. CÍCERO. De officcis (I.xi.34).

${ }^{71}$ H. GRÓCIO. De jure belli ac pacis (I.i. 2.1).

${ }^{72}$ A. GENTILI. De jure belli (I.ii).
} 
Bynkershoek aponta a sua definição da guerra, como 'a luta por meio da força e de artimanhas, daqueles que são independentes, na manutenção de seus direitos' ${ }^{73}$ A seguir, detalha cada um desses elementos. ${ }^{74}$

O capítulo II trata da muito controversa questão da necessidade ou-não de declaração de guerra, antes do desencadeamento das hostilidades. Nessa matéria Bynkershoek se reporta somente à razão e recusa a validade do argumento de Grócio quanto ao caráter indispensável da declaração de guerra. A legitimidade da guerra reduziria a necessidade da declaração formal: "ut bellum sit legitimum, indictionem belli non videri necessariam".

O capítulo III cuida da situação da guerra entre os inimigos (de statu belli inter hostes) e contém o ponto central do assunto tratado: a guerra, embora, ao menos em teoria indique relação entre os soberanos (principes), na prática acarreta que (toda) a nação se engaje nesta, e põe termo a todas as relações amistosas. O direito da guerra não conhece restrições e comporta o mútuo direito de vida e de morte.

Os capítulos IV a VII cuidam de vários aspectos relativos à captura de bens e propriedades do inimigo. ${ }^{75}$

O capítulo VIII começa a cuidar da questão complexa da neutralidade, que C. van Bynkershoek, inicialmente, considera do ponto de vista de ser ou-não legítimo perseguir ou atacar o inimigo em porto ou território neutro (an hostem liceat aggredi vel persequi in amici territorio vel portu): o espaço da guerra é o elo que une os braços desse golfo.

A guerra é praticada no território dos inimigos, ou no alto-mar, que é destituído de qualquer soberania. Mas com respeito ao território de nações não-envolvidas no conflito, e amigas de ambos os beligerantes.

A transgressão, em geral, da fronteira do território de estado em paz com o beligerante configura atentado ilegal contra os direitos soberanos de potência amiga, e altamente culpável. Constitui direito e mesmo dever de qualquer soberano prevenir e mesmo punir violação de tal ordem, seja praticada por via marítima ou terrestre. Conseqüentemente coibir qualquer ato de guerra seja praticado em seu território, bem como determinar que quaisquer presas tomadas, sejam devolvidas aos seus titulares.

\footnotetext{
${ }^{73}$ BYNKERSHOEK, C. van. Quaestionum juris publici (Liber I. caput I): bellum est eorum, qui suae potestatis sunt, juris sui persequendi ergo, concertatio per vim vel dolum.

74 Id.: "Videamus singula".

75 BYNKERSHOEK, C. van. Quaestionum juris publici (Livro I) caput IV: Ecquando res hostium mobiles, \& praesertim naves, fiant capientium ? ; caput $\mathrm{V}$ : Res móbiles, \& praesertim naves, na \& quosque recuperatori cedant ? ; caput VI : Quousque extendaturimmobilium possessio, bello quaesita; caput VII : Hostium actiones \& credita, quae apud nos inveniuntur, an exorto bello recte publicentur.
} 
Numerosos exemplos mostram, contudo, que esse princípio foi, muitas vezes, simplesmente deixado de lado. ${ }^{76}$ Bynkershoek cita a destruição pelos holandeses da frota espanhola, no Porto de Downs, em 1639, bem como o cerco à esquadra holandesa da Companhia das Índias Orientais, pelos ingleses, no Porto norueguês de Bergen, em 1665, não-obstante a ferrenha oposição dos dinamarqueses.

Bynkershoek propõe a diferença entre a agressão e a perseguição. ${ }^{77}$ Se a primeira é absolutamente proibida, a perseguição de navio em fuga, ou de uma esquadra, no limite marginal marítimo, ou de divisão fugitiva, na fronteira terrestre de potência neutra, deveria ser admitida sob a condição de que as fortificações da potência amiga sejam respeitadas, e nenhum dano seja causado aos súditos desta. O início e a continuação da ação são duas coisas distintas. A diferença, contudo, muitas vezes é negligenciada, ${ }^{78}$ nos costumes do tempo e somente pode Bynkershoek recomendar a sua opinião como orientação segura. ${ }^{79}$

O capítulo IX considera a questão da guerra em relação aos não-beligerantes (de statu belli inter non hostes). Serve para mostrar quanto a questão da definição, do conteúdo e dos efeitos da neutralidade era premente para os contemporâneos de Bynkershoek, como permanece até os nossos dias.

Os neutros, denominados por Grócio aqueles que ficam em meio à guerra (In bello medios dixit Grotius), ${ }^{80}$ são apresentados como nem inimigos, nem amigos. Os neutros devem ser cuidadosamente distinguidos dos aliados, que ficam, em razão de tratados, obrigados em relação a um ou a ambos os beligerantes. ${ }^{81}$

Os neutros nada têm a ver com o conflito e, aparentemente, devem ficar longe do alcance dos efeitos deste, de modo a poder dar continuidade às suas relações amistosas, com ambos os beligerantes. Na verdade, contudo, o dever de estrita abstinência de qualquer interferência incumbe aos neutros e os obriga a não efetuarem qualquer fornecimento de homens ou armas, munições ou materiais, aptos ao uso militar ou naval, e mesmo de alimentos ou outras mercadorias, muitas vezes objeto de especificações detalhadas.

\footnotetext{
${ }^{76}$ BYNKERSHOEK, C. van. Quaestionum juris publici (I.VIII): "Ex his licet intelligere, quo jure quave injuria censenda sint sequentia exempla".

${ }^{77}$ Cfr. a respeito o conteúdo da Convenção das Nações Unidas sobre o direito do mar (1982) denomina "hot pursuit".

${ }^{78}$ BYNKERSHOEK, C. van. Quaestionum juris publici (I.VIII): "Atque ita quidem non absurde disputare \& distingui videtur posse."

79 BYNKERSHOEK, C. van. Quaestionum juris publici (I.VIII): "sed haec omnia non exsequor, quia de iis ipse judicabis, adhibita distinctione, quam modo suggessi, si haec \& tibi aeque placeat, quam mihi".

${ }^{80}$ GRÓCIO, H. De jure belli ac pacis (III.17).

${ }^{81}$ BYNKERSHOEK, C. van. Quaestionum juris publici (I.IX): "Non Hostes appello, qui neutrarum partium sunt, nec ex foedere his illisve quicquam debent; si quid debeant, Foederati sunt, non simpliciter amici."
} 
O dever de neutralidade é absoluto, e desvinculado de qualquer avaliação quanto à justiça ou injustiça da guerra. Não cabe ao amigo julgar dos motivos e da justiça de causa que diz respeito a outros, e não se submete ao seu julgamento. ${ }^{82}$

A estrita abstinência de qualquer participação no conflito, por parte do neutro, somente se pode justificar por causa do medo de se tornar vítima do vencedor. Nesse caso, contudo, a participação abertamente assumida seria preferível à fictícia neutralidade.

Com relação aos aliados, a situação é distinta. Se estes se engajam no conflito, com outros, podem clamar pela ajuda de seus aliados. Se isso se dará em relação a um ou ao outro, Bynkershoek opina que o aliado de ambos os beligerantes terá de escolher segundo ao aliado pareça acudir melhor razão, e se alinhe com este. Aqui parece desviar-se Bynkershoek de sua orientação geral quanto aos terceiros não se imiscuírem no julgamento da justiça de conflitos que não sejam seus.

Somente a interpretação escrupulosa de tratado de aliança poderá levar à determinação da escolha entre casus foederis, para averiguar se a hipótese contemplada efetivamente ocorreu. ${ }^{83}$ De novo, Bynkershoek opina no sentido de que termos vagos e equívocos devam ser interpretados, de tal modo que somente uma justa causa possa justificar o apelo a uma potência aliada.

$\mathrm{O}$ capítulo $\mathrm{X}$ (de his, quae ad amicorum nostrorum hostes non recte advehuntur) trata, com o capítulo XI (obsessis urbibus, castris, portubus na quicquam liceat advehere?) das duas mais importantes matérias da neutralidade: o contrabando e o bloqueio. A doutrina do contrabando é tangencialmente introduzida, a partir de consideração do Direito Romano a respeito. A distinção grociana entre as categorias de bens que nunca, sempre ou algumas vezes são destinados a propósitos bélicos encontra pouca acolhida, por parte de Bynkershoek. Questiona tenha tal distinção qualquer utilidade, e possa ser, na prática, observada.

A questão do bloqueio ${ }^{84}$ é afirmada como não-admissível, e a opinião de Bynkershoek é claramente afirmada, como contrária a qualquer fornecimento, de bens, sobretudo munições e provisões, destinadas a praças, contra as quais medidas militares devam ser empenhadas. Enfaticamente combate a opinião de Grócio, no sentido de que a ilicitude da prática dependeria de estar ou-não conectada à expectativa de rendição próxima, ou do final da guerra, e que a violação do bloqueio possa ser objeto de indenização ou de

\footnotetext{
${ }^{82}$ De LOUTER, Jan (introduction, 1922, p. xviii) considera estar, nesse tópico, Bynkershoek à frente de Grócio, porquanto este último se teria enredado na distinção inextricável a respeito da guerra justa ou injusta. Comparese GRÓCIO. De jure belli ac pacis (livro III, cap. XVII, seção 3).

${ }^{83}$ BYNKERSHOEK, C. van. Quaestionum juris publici (I.IX): "Hi, qui sub tuitione sunt (die onder contributie sitten) constituunt etiam genus quoddam intermedium, nam ex natura tuitiones non considerandum tanquam hostes, neque etiam tanquam subditi, cum ad akium Principem pertineant".

${ }^{84}$ BYNKERSHOEK, C. van. Quaestionum juris publici (I.XI): "Ex ratione communi \& gentium usu Urbibus obsessis nihil quicquam licet advehere".
} 
compensação do poder sitiante, lesado por tal operação. Argumenta, com correção, no sentido de que a probabilidade ou a proximidade do desfecho do conflito fica além do alcance dos neutros, e que o dano ao poder sitiante, causado pela violação do bloqueio em muito excede os limites de mera indenização, e somente pode ser contrabalançado por confisco maciço, e mesmo de punições corporais. Isso não-somente como ditame da reta razão, mas como prática freqüentemente estipulada em convenções celebradas pelos Estados Gerais das Províncias Unidas dos Países Baixos.

Os capítulos XII a XV introduzem a questão do direito das presas. ${ }^{85}$ Diferenças de tratamento podem ocorrer entre o navio e a carga, ou mesmo entre distintas partes da carga.

As hipóteses mais freqüentes, de mercadoria neutra em navios inimigos, e de mercadoria inimiga em navios neutros, são reguladas nos capítulos XIII e XIV. De forma consistente com a sua opinião da legitimidade do comércio neutro com cada um dos beligerantes, Bynkershoek prevê a possibilidade de estrita separação do navio inimigo, que pode ser detido e confiscado, em relação à carga neutra, que deve ser respeitada e liberada. $^{86}$

De tal situação, passa a considerar Bynkershoek, a inversa, na qual a mercadoria inimiga se encontre em navio neutro. $\mathrm{O}$ mesmo deveria prevalecer.

Grócio, alinhado pelo Direito Romano, que coibia a prática de prevaricação, entendia que o confisco deveria ser limitado aos casos de notório conhecimento, pelo armador, do caráter ilícito das mercadorias embarcadas. Isso sempre ocorre quando o mesmo indivíduo desempenhe várias dessas funções, simultaneamente, porquanto o conhecimento de embarque conterá as especificações relativas a todas as mercadorias levadas a bordo, de tal modo que se possa presumir a responsabilidade.

Bynkershoek, contudo, não insiste nesse ponto e considera que mesmo quando se saiba do caráter ilícito, das mercadorias de propriedade do inimigo, trazidas a bordo, não se pode presumir a prática de ilícito, exceto quando se tratar de contrabando ou de transportar mercadorias para praças sujeitas a bloqueio.

O capítulo XV reverte ao Direito Romano (an res, ab hostibus captae, in non hostis imperium delatae, postliminio revertantur) que prevê a restituição de pessoas e bens

\footnotetext{
${ }^{85}$ BYNKERSHOEK, C. van. Quaestionum juris publici (Liber I): caput XII: An licitum ob illicitum publicetur?; caput XIII: De amicorum bonis, in hostium navibus repertis ; caput XIV : De hostium rebus, in amicorum navibus repertis".

${ }^{86}$ No mesmo sentido a previsão que se continha na consolidação de normas marítimas, Consolato del Mare (séc. XIV). Exigir-se-ia, contudo, o pagamento de frete, condição essa claramente rejeitada por Bynkershoek, porquanto o frete somente seria exigível sobre o transporte efetuado e a mercadoria entregue no porto de destino. As perdas de tempo e de dinheiro já onerariam suficientemente o imprudente dono dos bens que as tivesse embarcado em nave inimiga, durante a ocorrência de conflito armado, do qual resultasse a apreensão do navio e da respectiva carga, por forças inimigas.
} 
que tenham perdido a sua condição, por conquista ou captura, e se encontrem reduzidos à condição de escravidão ou de dominação estrangeira, à sua anterior condição, por meio da devolução a seu próprio país ou a um dos aliados. Alguns consideram que bastaria tratar-se de neutro que faça o resgate. Bynkershoek, contudo, concorda com Grócio, ao enfatizar que se trate de restauração à condição anterior, somente nos casos em que se dê o retorno ao próprio país ou a um de seus aliados, e acrescenta aos exemplos, aduzidos por Grócio algumas hipóteses racionais, tais como as interpreta.

No caso de aliado, este, logicamente restaurará à sua condição jurídica original, o que tenha tomado, ou liberado, do inimigo comum; o neutro, por sua vez, nunca pode mudar, mesmo em virtude de sentença judicial, as conseqüências legítimas da guerra, nem tampouco legalmente restaurar propriedade adquirida de proprietários anteriores, que em virtude de norma jurídica tenham sido privados do título de propriedade que detinham, porquanto este se veria afastado do seu dever de manter-se no estrito dever de não-causar qualquer interferência.

As normas nessa matéria não dizem respeito somente a indivíduos, como também a entidades públicas e nações inteiras, na linha do que já observara Grócio. Nesse sentido, o capítulo XVI (de jure postliminii varia) faz exame da história holandesa, a respeito do tema.

O capítulo XVII, por sua vez, considera os efeitos de atos de pirataria sobre a titularidade de propriedade (de piratica, \& an Barbari in Africa sint piratae) que não se pode transferir por meio destes atos. Piratas são todos os que pratiquem tais atos, sem estarem dotados de cartas de corso - o que os classificaria como corsários. E, conseqüentemente, conferiria caráter oficialmente sancionado pelo poder soberano que a eles tivesse conferido tal titulação.

O caminho da pirataria aos atos privados é regulado nos capítulos XVIII (de predatoria privata), XIX (quousque exercitores navis praedatoriae teneantur de damno injuria dato?) e XX (si navis, non ad praedandum emissa, praedam tamen ceperit, ad quem ea pertineat?). Constitui parte importante do Direito Público, não-somente por se tratar de exigência de consentimento da autoridade, como em razão dos incessantes conflitos e gravames que suscita.

A questão dos seguros marítimos, não conhecida ao tempo dos romanos, é considerada merecedora de regulação, conforme o capítulo XXI (an res hostium liceat assecurare?). Na medida em que o seguro constitui a assunção do risco que, originalmente, caberia ao dono do bem assegurado, mediante remuneração, e prestar assim a este proprietário, assistência para a consecução de seus fins, será, evidentemente, proibido assegurar bens e navios, que tenham caráter inimigo, mesmo se algum lucro daí pudesse resultar para o segurador. 
É lícito alistar soldados em país neutro? - a questão, muito em voga, ao tempo de Bynkershoek, é o objeto do capítulo XXII (an liceat militem conducere in amicae Gentis populo?). ${ }^{87}$

O capítulo XXIII (an singulis Belgiae foederati Provinciis jus sit belli gerendi?) cuida da matéria de saber se uma das províncias, separadamente considerada, poderia decidir engajar-se em operação de guerra. Bynkershoek entende pela negativa, e considera que isso atentaria contra os fundamentos da República. O capítulo XXIV (de repressaliis nonnulla, \& an earum quoque jus sit penes singulas Provincias?), por sua vez, ao considerar a questão das represálias, traz termo e conceito que não era conhecido dos antigos romanos.

O capítulo XXV, e último, aduz às questões já tratadas no Livro I, algumas observações sobre tópicos diversos (variae quaestiunculae), não extensamente desenvolvidas. O interesse destas é bastante desigual. Algumas consideram episódios da história das Províncias Unidas, como a evacuação de fortaleza, em território neutro, depois do recebimento de ordem equivocada, ou a indenização, em vão requerida por uma das províncias, em razão de danos sofridos, durante a guerra de 1672

O Livro II (de rebus varii argumenti) das Questões de direito público, tem configuração bastante mais variada. Cuida de assuntos bastante diversificados, e de importância muito variada.

Os dois primeiros capítulos cuidam de questões relacionadas com a história das Províncias Unidas, capítulo I (comitum potestatem in Belgio Foederato non cessasse nisi past 26. Jul. 1581) e capítulo II (ex consilio non fraudulento neminem Reipublicae obligari, nec etiam quemquam recte puniri, quod mandatum Principis sui exsequutus sit) mas podem aceder a dimensão mais ampla. Uma nação não pode ser chamada à responsabilidade por mudança de governo, no interesse da paz e da tranqüilidade.

Os sete capítulos seguintes, III até IX, ${ }^{88}$ por assim dizer completam o tratado no De foro legatorum. Este, muitos anos antes, tinha contribuído para firmar a reputação do Autor, em relação ao tema da natureza jurídica e da atuação dos agentes diplomáticos.

\footnotetext{
${ }^{87}$ Fenômeno, ademais, que se produz até hoje, como mostram casos noticiados de brasileiros, residentes, por exemplo, nos Estados Unidos, que se alistaram nas forças armadas desse estado, e como tais foram enviados, para combater na invasão do Iraque, a partir de 2003. Cumpre observar ter o Brasil manifestado a sua oposição a tal invasão e ter permanecido neutro no conflito. Cabe indagar se deveria ou não, em tais casos, ocorrer a perda da nacionalidade de origem? O entendimento no sentido positivo se reforça ante a circunstância de se tratar de voluntário alistamento e engajamento às forças armadas de país estrangeiro.

${ }^{88}$ C. van BYNKERSHOEK, Quaestionum juris publici (Liber II): caput III: qui recte Legatos mittant; caput IV: an singulae Provinciae Foederati Belgii Legatos possint mittere, vel accipere? ; caput V: qui recte Legati mittantur; caput VI: Legati quid rerum olim egerint, \& nunc agant, cum publice audiuntur; caput VII: an valeat quod Legatus egit contra arcanum mandatum?; caput VIII: an Legatis donum munus accipere liceat? \& alia ejusdem argumenti; caput IX: quaedam de praerogativa ordinis inter Legatos, \& inter Principem minorem praesentem \& majoris absentis Legatum.
} 
Enceta o exame do tema Bynkershoek com a indagação, no capítulo III, a respeito de quem pode enviar embaixadores? Responde que somente podem ser enviados embaixadores por um soberano a outro soberano. De uma nação soberana a outra, sejam estas monarquias ou repúblicas. Pessoas que representem súditos, ou rebeldes, embora mais ou menos organizados, não se revestem de tal condição, e conseqüentemente não podem ter enviados que gozem das plenas prerrogativas da condição de embaixadores.

A realidade predomina no Direito Internacional como espécie de marco ou limitação contra incertezas insolúveis e discussões sem fim. Essa norma estrita, contudo, em nada impede que se enviem e se recebam incontáveis representantes e mensageiros, de entidades provinciais, municipais, ou outras categorias de entes políticos subordinados, e que se lhes concedam equivalentes privilégios e similar tratamento, em decorrência de tratamento de cortesia, ou mutuamente acordado.

O capítulo IV aplica tais princípios às Províncias Unidas dos Países Baixos, e indaga se o direito de enviar embaixadores pertence, exclusivamente, ao governo central, ou pode ser reconhecido, também às diferentes províncias, separadamente consideradas. Fiel aos seus princípios republicanos, Bynkershoek sustenta que ao se reunirem em pacto federativo, as Províncias Unidas somente se teriam privado daquelas prerrogativas às quais tivessem explicitamente renunciado, e que de outra forma, estas renúncias não se presumiriam, em relação aos casos, para os quais não tivessem sido explicitamente dadas. Tudo isso, para tentar justificar o acordo dos Estados da Província da Holanda, com o Governo inglês, por ocasião da paz de 1654, concernente à exclusão dos direitos da dinastia de Orange, que desse modo, novamente expunham as insuficiências de constituição, que carecia de qualquer coesão e espalhava os mais perigosos germes de dissolução e de ruína.

O capítulo $\mathrm{V}$ comenta brevemente as exigências necessárias para o exercício da função de embaixador. Judiciosamente observa Bynkershoek quanto o cuidado em nãocomprometer o seu soberano deve nortear a atuação do embaixador, no sentido de que este construa representação adequada de quem o envia.

Ao prosseguir no exame do direito de legação, enfatiza Bynkershoek, no capítulo VI, que não se deve insistir em questões fúteis de cerimonial - nolim enarrare cerimonias -, mas ater-se a visão funcional da matéria e conferir-lhe tratamento consentâneo com os fins a que se destina. Fixa a atenção nas suas tarefas e nos seus deveres. Não são fins em si mesmos, nem devem servir como privilégios pessoais, mas devem ser entendidos e interpretados como atribuições funcionais, conferidas para permitir o adequado desempenho de suas funções profissionais.

Os embaixadores logicamente se vêem vinculados por suas cartas de missão e pelos limites das suas atribuições, como representantes do príncipe que os envia - falleris, si putes, Legatum esse aliud quicquam, quam mandatarium Principis 
sui - e como tais têm as suas atribuições determinadas. Os instrumentos de nomeação, regulados no capítulo VII, são normalmente de duas naturezas: o primeiro instrumento, oficial, público, breve e, normalmente, padronizado; enquanto o segundo, particular, chamado instrução, secreto, explícito, e extremamente variado, no tocante à forma e ao conteúdo. Suscita Bynkershoek a questão com relação à atuação dos embaixadores, se as suas ações, em conformidade com os poderes plenipotenciários, mas contrárias às suas instruções, seriam obrigatórias em relação ao seu próprio governo. À questão, de grande importância, Bynkershoek responde de forma diversa de Grócio e de Gentili, no sentido de que estes erroneamente estimariam fossem tais ações ao menos vinculantes, pois de outro modo, o soberano que recebe o representante se veria frustrado, em relação às suas legítimas expectativas. Ele defende a opinião contrária e procura demonstrar que em caso de instrumento público de poderes plenipotenciários, detalhado em pontos distintos, a sua execução pelo embaixador teria caráter vinculante. Mas, se for este instrumento público de caráter genérico, como normalmente é o caso, a instrução específica, embora secreta, se torna vinculante, restringirá as competências do embaixador e, conseqüentemente, somente os seus procedimentos, em conformidade com as suas instruções se revestirão de força vinculante.

Prática sempre freqüente, os presentes entre soberanos são objeto de tratamento por Bynkershoek, em seu capítulo VIII, do livro II das Quaestionum juris publici, e tais demonstrações de estima recíproca e de amizade, em momento no qual o representante de soberano estrangeiro deixa seu posto no Exterior, onde exercitara as suas funções, são de uso corrente, e consideradas cortesia habitual.

O último capítulo sobre o direito de legação (IX) trata da então pouco consolidada questão da classificação dos embaixadores. ${ }^{89} \mathrm{Na}$ medida em que os soberanos se põem em pé de igualdade, uns em relação aos outros, da mesma forma deveria ocorrer, entre os seus representantes, juntos aos governos estrangeiros.

A matéria tinha complicação adicional, na medida em que então ainda se pretendia estabelecer hierarquia entre os soberanos propriamente ditos, o que constitui questão insolúvel. Como não existe poder superior, nem árbitro competente, para solucionar a questão, a ocorrência de opiniões divergentes, dos vários autores, não têm autoridade, e se mostram de escassa utilidade.

Sugestiva esta passagem do livro II, cap. IX: "Sunt tamen, qui illud mandatum humanitati magis, quam juri tribuunt." Certamente não se pode dizer isso, mas pode parecer que, de certo modo, Bynkershoek intuitivamente antecipa a idéia de

\footnotetext{
${ }^{89}$ BYNKERSHOEK, C. van. Quaestiones juris publici libri duo (II, caput IX, cit.): quaedam de praerogativa ordinis inter Legatos, \& inter Principem minorem praesentem \& majoris absentes Legatum.
} 
embaixadores da humanidade, ${ }^{90}$ tal como viria a ser inscrita nos tratados em matéria de Direito Internacional Espacial?

$\mathrm{O}$ capítulo $\mathrm{X}$ contém a matéria mais relevante do livro II, a questão do conteúdo vinculante dos acordos internacionais (de servanda fide pactorum publicorum, \& an qua eorum tacitae exceptiones?). Bynkershoek enceta o exame da questão com a afirmação de que os pactos privados são regidos pelo Direito Civil e os pactos entre soberanos pela boa-fé: Pacta privatorum tuetur Jus civile, pacta Principum bona fides. ${ }^{91}$ De tal modo que se se destrói a boa-fé, destroem-se todas as relações entre os soberanos, porque as relações entre estes dependem expressamente de tratados. Destruir-se-á também o Direito Internacional, porquanto este tem origem em acordos tacitamente aceitos e pressupostos, fundados na razão e no uso.

Bynkershoek considera a questão delicada da conservação da validade dos compromissos internacionais, dada a mutação substancial de circunstâncias. Embora a norma geral seja claramente esposada por ele - fidem pactorum esse servanda - com base na boa-fé, não se pode negar o impacto que pode acarretar a modificação de circunstâncias sobre a viabilidade da continuidade de qualquer acordo, seja este público ou privado, interno ou internacional. Entre as muitas nações independentes, não há compulsão jurídica, porque as leis não se aplicam às relações internacionais, e a única fonte de compulsão é o Direito, mas entre as nações se mantém as promessas, com base na boa fé e na utilidade pública. ${ }^{92}$

Bynkershoek sabia a respeito do que falava. Encerra o importante capítulo X, do livro II, das Quaestionum juris publici, com a ponderação seguinte: mas, como ensina a prudência, e convém omitir os detalhes, além do que já foi dito; as nações, em

\footnotetext{
90 ACCIOLY, V. H.; SILVA, G. E. do Nascimento e; CASELLA, P. B. Manual de direito internacional público. 16. ed. São Paulo: Saraiva, 2008, esp. item 5.8.2. 'espaço ultraterrestre'). Em 22 de abril de 1968, foi aberto à assinatura o Tratado sobre o salvamento e a devolução de astronautas e a restituição de objetos lançados ao espaço ultraterrestre, com determinações específicas sobre a assistência obrigatória de todos os estados a astronautas, independentemente de suas nacionalidades. Desde os primeiros anos da conquista do espaço, prevê-se que um astronauta deveria ser considerado "embaixador da humanidade", de modo a assegurar-lhe tratamento condigno. Em caso de acidente e queda, em território de outro estado deveria ser prontamente restituído ao seu país de origem, e este será responsável pelas despesas correspondentes. Da mesma forma, estabelece regra semelhante para objetos espaciais encontrados em territórios de outros Estados, de forma a impedir a apropriação de tecnologia estratégica contida nesses equipamentos.

91 BYNKERSHOEK, C. van. Quaestiones juris publici libri duo (II, caput X) prossegue: "Hanc fi tollas, tollis mutua inter Principes commercia, quae oriuntur e pactis expressis, quin \& tollis ipsum Jus gentium, quod oritur e pactis tacitis \& praesumptis, quae ratio \& usus inducunt."

${ }^{92}$ BYNKERSHOEK, C. van. Quaestiones juris publici libri duo (liber II, caput X): "Inter diversas quidem Gentes, quae sui juris sunt, nihil est, quod jure cogat, filent enim leges, \& ex legibus sola vis cogendi, sed ut inter Gentes promissis stetur, suadet bona fides \& utilitas publica."
} 
geral, são constituídas, de tal modo, que nem se pode atribuir-lhes a flagrante traição, nem tampouco se devem buscar nelas exemplos destacados de magnanimidade. ${ }^{93}$

O capítulo XI considera se estrangeiros devem ser mantidos fora de empregos públicos (an peregrini ab administratione Reipublicae sint arcendi?). Especifica Bynkershoek que, ao mencionar os estrangeiros não tem em mente aqueles que vivam no Exterior, em relação aos quais ninguém cogitaria de ir buscá-los, para virem exercer empregos públicos, mas àqueles que "vieram para nosso país e transferiram para cá os seus bens e os seus interesses" ${ }^{94}$ Em relação a estes, considera Bynkershoek não haver motivo para excluir de funções e dignidades públicas, os estrangeiros, que vivam no país, estejam familiarizados com a língua e os costumes, desde que não exista receio de indevida interferência ou ascendência, de modo a justificar tal exclusão. A lição deste deveria ser refletida no âmbito da União Européia atual. ${ }^{95}$

O capítulo XII considera a possibilidade de transmissibilidade de império e de jurisdição (imperium \& jurisdictio an possint mandari?). A abdicação de soberania era vetada pelo Direito Romano, mas pode ser sancionada por modalidades de delegação de jurisdição. ${ }^{96}$

No capítulo XIII examina Bynkershoek se débitos públicos podem ser imputados a particulares (an ob debitum Universitatis singula membra conveniri \& damnari possint?). Indivíduos, integrantes de corporação pública, não podem ser responsabilizados por débitos ou créditos da comunidade, sejam estes decorrentes de Direito Civil ou Penal.

O capítulo XIV trata de questão de pouca relação direta com o Direito Internacional atual. Indaga se se poderia fazer a reparação de fortalezas, sem o consentimento prévio e expresso do soberano (an liceat Urbes, earumque moenia exstruere, reficere, extendere, munire sine consensus Principis?).

Por sua vez, o capítulo XV considera a questão da possibilidade e das modalidades de expropriação (de dominio eminenti nonnulla, \& de refundendo pretio

\footnotetext{
${ }_{93}$ BYNKERSHOEK, C. van. Quaestiones juris publici libri duo (liber II, caput X): "Sed prudentiae erit haec omnia omittere, hoc duntaxat superdicto : omnium Rerumpublicarum han ferem indolem esse, ut neque grandem perfidiam iis recte objeceris, nequem singularem animi magnitudinem ab iis facile expectaveris."

${ }^{94}$ BYNKERSHOEK, C. van. Quaestiones juris publici libri duo (liber II, caput XI): "eos, qui origine quidem peregrini sunt, in nostrum tamen Imperium concesserunt, eo translata rerum ac fortunarum suarum sede".

${ }^{95}$ Não-obstante a importância basilar das liberdades de circulação e de estabelecimento, e que há muito seja realidade a igualdade de tratamento entre os nacionais dos diferentes estados, integrantes da União Européia, com a proibição de distinções, em decorrência da nacionalidade, ao menos para o setor privado, até hoje é problemática a questão do acesso e do exercício de funções públicas por estrangeiros, o que, em considerável medida, todavia constitui espécie de 'reserva de mercado'.

${ }^{96}$ Novamente, em relação a esta matéria, poder-se-ia dizer ter havido antecipação de alguns séculos, até que se institucionalizasse, a partir do início da segunda metade do século XX, no âmbito da União Européia, a divisibilidade de competências soberanas, entre a União e os Estados-membros.
} 
eorum, quae jure ejus dominii occupantur). Bynkershoek faz derivar esta matéria do conceito de domínio eminente, na linha da terminologia adotada por Grócio.

Dois capítulos bem estruturados e fundamentados, a respeito de Direito Criminal, mostram a formação e a linha do magistrado e presidente de tribunal. O capítulo XVI considera a questão de remissão de penas (ut solius Principis est crimina remittere, sic ejus solius esse videri, criminum impunitatespublice promittere) e o capítulo XVII (judices extra territorium suum non recte exilium indicere, nisi ex privilegio Principis), a respeito da pena de banimento, considerada irracional, na medida em que envia criminosos de um país para outro, e acaba por acarretar um jogo de empurra-empurra de resíduos danosos, para o tecido social.

Os três capítulos seguintes ${ }^{97}$ procedem ao exame de certas leis e instituições das Províncias Unidas dos Países Baixos, ao tempo de Bynkershoek. Para o tempo e o meio, no qual foram exaradas, caberia deter-se nas querelas religiosas, que tantas vezes abalaram até os fundamentos da República.

A união de Utrecht, em 23 de janeiro de 1579, enfaticamente declarara cada Província soberana em matéria de religião, e estritamente proibia qualquer interferência em matéria de organização eclesiástica. Estas questões se põem em relação direta com a tradição holandesa de estrito respeito e observância da liberdade de consciência e de religião.

O capítulo XXI retoma matéria de Direito Internacional, embora possa parecer, em nossos dias, curioso ou mesmo totalmente ultrapassada a questão de cerimonial marítimo e de procedimentos de saudação entre navios de diferentes bandeiras (quando \& quorum navibus praestanda sit reverentia? \& andamnum, quod ob reverentiam non praestitam accipitur, commune sit, ut in jactu?). Bynkershoek remete ao seu estudo anterior, De dominio maris dissertatio e enfatiza a distinção a ser feita, quanto ao regime aplicável às faixas costeiras, subordinadas à soberania do Estado, cujo território é banhado por aquelas águas, em relação ao alto-mar, enquanto espaço comum, não-subordinado à soberania de qualquer Estado.

O capítulo XXII considera questões várias relativas a tributos (varia de tributis, vectigalibus \& publicanis). Bynkershoek faz a distinção entre impostos, enquanto pagamentos decorrentes de atribuição pessoal de propriedade (tributa), em relação a imposições decorrentes de operações de exportação e de importação de bens de consumo

\footnotetext{
${ }^{97}$ BYNKERSHOEK, C. van. Quaestiones juris publici libri duo (liber II), caput XVIII : an jus Religionis, ut olim fuit, ita nunc quoque sit penes singulas Provincias?; caput XIX: optimo jure ordines Hollandiae 13. Mart. 1663. Ecclesiastis praescripsisse novam orandi formulam cum pro fé, tum pro aliis Magistratibus ; caput XX: interpretatio par. 4 Pacis Monasteriensis 30. Januar. 1648.
} 
(vectigalia). Demonstra que a tributação em uma República não exige menos sacrifícios que em uma monarquia e muitas vezes se imiscui em detalhes diários da vida social.

Os dois capítulos seguintes ${ }^{98}$ voltam a tratar de intrincadas questões constitucionais das Províncias Unidas dos Países Baixos.

O capítulo final traz estranha miscelânea de reflexões sobre temas variados (variae quaestiunculae). Inicialmente aponta que nenhuma mudança na estrutura do Estado pode acarretar a remissão de quaisquer dívidas ou obrigações, anteriormente contraídas. ${ }^{99}$

Ainda nesse mesmo capítulo final, a seguir formula breve notícia sobre a prática da deportação, pelas diferentes cortes provinciais. Em seguida argumenta que mesmo governo ilegal deve ser respeitado, e obedecido, por seus súditos, exceto se atuar notoriamente fora dos padrões normativos habituais. Breve nota sobre a incapacidade dos estrangeiros para julgarem as relações internas, precede recomendação a respeito da conveniência e da utilidade do revezamento, na determinação de lugares e de critérios de precedência, em reuniões internacionais, em lugar de se observar a ordem temporal de chegada.

Em seguida, recrimina Zouch por pretender a generalização da severa norma inglesa, no sentido de se proibir a qualquer inglês a mudança de nacionalidade, sem o expresso consentimento do soberano. Entende Bynkershoek ser lícito e legítimo que alguém decida alterar o seu domicílio e vinculação nacional, desde que todas as obrigações devidas ao governo tenham sido estritamente cumpridas. ${ }^{100}$

Considera, ainda, Bynkershoek, nesse mesmo heteróclito capítulo final de seu tratado sobre questões de Direito Público, que se um tratado abolir encargos especiais, às custas de corporações subordinadas, estas devem ser devidamente indenizadas. A recepção de soberano estrangeiro deve ser feita pelos órgãos dirigentes da Confederação, e não por parte de qualquer de seus membros.

\footnotetext{
${ }_{98}$ BYNKERSHOEK, C. van. Quaestiones juris publici libri duo (liber II), caput XXIII: an Ordines Generales recte sese immisceant controversiis singularum Provinciarum?; caput XXIV: de modis conciliandi dissentientes Provincias. O mesmo assunto fora, antes, mencionado, nos dois penúltimos capítulos do Livro I, onde se defendera o direito de guerra e do exercício de represálias, pelas distintas Províncias, separadamente consideradas, e mais explicitamente, nos capítulos IV, XIII, XVIII, do Livro II, onde a pretensa soberania das Províncias é descrita, em relação a questões relacionadas à diplomacia, finanças e religião.

${ }^{99}$ Esse tópico se inscreve como um dentre outros, em matéria de efeitos de sucessão de estados. A respeito, a tentativa de codificação, por meio da Convenção de Viena sobre sucessão de estados em matéria de bens, dívidas e arquivos de estado (1983). A respeito, v. ACCIOLY, V. H.; SILVA, G. E. do Nascimento e; CASELLA, P. B. Manual de direito internacional público. 16. ed. São Paulo: Saraiva, 2008, item 1.4.5. Convenções de Viena em matéria de sucessão de estados).

${ }^{100}$ Nesse sentido, a situação no direito brasileiro vigente, onde pode o cidadão brasileiro mudar-se para o exterior e lá passar a ser residente, inclusive para fins tributários, desde que tenha quitado tributos nacionais devidos até então.
} 
Títulos de nobreza, concedidos por soberanos estrangeiros, são inofensivos e não devem ser proibidos, mas não podem acarretar a concessão de privilégios restritos à nobreza local.

Finalmente, dano e depredações, causadas por convulsão social ou guerra civil não podem deixar de ser objeto de indenização, seja por parte dos oficiais encarregados, seja em relação a particulares, caso se prove terem as autoridades deixado de atuar, com a diligência devida, e possam condicionalmente ser consideradas responsáveis.

Em suma, pode-se contemplar o conjunto das matérias, abrangidas pelas Quaestiones juris publibi, de Bynkershoek, para chegar à conclusão de que este tratou do conjunto das matérias do Direito Internacional de seu tempo. ${ }^{101}$ Assim, esse tratado exibe todo o conhecimento e os conceitos sobre esse ramo do direito, tal como tinha ocupado o seu Autor.

Ao mesmo tempo, desconsidera a estrita divisão entre Direito Internacional e Direito Público interno, e livremente mescla questões de Direito Internacional Público, em sentido estrito, com outras de relações internacionais, àquelas que dizem respeito somente ao Direito Constitucional interno do seu país, e como tais regidas por normas e usos internos. O resultado é imbricação de temas nem sempre fácil de ser desmembrada.

A doutrina da neutralidade, tal como a formula Bynkershoek, vai além da formulação que antes adotara Grócio. Este só incidentalmente tinha mencionado os neutros, e destes pouco se ocupara, enquanto Bynkershoek distingue, acertadamente, neutros de aliados, e caracteriza os direitos e os deveres de cada categoria. Os tópicos a respeito da neutralidade constituem ponto alto desse tratado.

Bynkershoek era jurista eminente, mas nem filósofo, nem moralista. Para ele, o Direito se põe como regulador da vida social. Sua atuação jurisprudencial fortemente o influenciou rumo ao papel do Direito Positivo e dos precedentes. Utilizou seus conhecimentos de Direito Romano e de Direito Civil para suprir lacunas que percebia, no estudo e no tratamento de questões de Direito Internacional. Ao proceder desse modo, a razão era o seu guia confiável, e a dedução lógica, o seu instrumento experimentado.

Enfatiza o papel da razão, e muitas vezes a denomina a alma ou a senhora do direito das gentes. Ao mesmo tempo em que ressalta a importância, tal como positivamente assevera ou tacitamente pressupõe, que os ditames da razão coincidam com os usos ou o costume reiterado, o primeiro de todos os tiranos, o principal mestre e o padrão de conduta, em matéria de Direito Internacional. ${ }^{102}$

\footnotetext{
101 Jan De LOUTER (introduction, 1992, cit., p. x1): «His preceding dissertations were monographs called forth by accidents but quite insufficient to give a clear idea of the extent and importance of the law of nations in general.» Ai se inscrevem, por exemplo, os capítulos III até IX, do Livro II, das Quaestiones juris publici, que complementam o que não tinha sido tratado no De foro legatorum.

102 BYNKERSHOEK, C. van. Quaestiones juris publici libri duo (livro I, caps. VI e X; livro II, cap. VII).
} 
Quando ocorre discordância, deixa a opinião de Grócio e parte para a defesa da razão, ${ }^{103}$ que aponta como o verdadeiro direito das gentes, não-obstante as distorções, decorrentes dos usos e costumes, decorrentes de prescrições legais, ou mesmo estipuladas em tratados. ${ }^{104}$ Assim, a exata relação entre as duas fontes permanece sem esclarecimento.

Se de um lado é relevante a preocupação de Bynkershoek com a fundamentação do direito das gentes a partir da prática, na medida em que Grócio fundamentara o volume maior de sua argumentação na razão natural, o conjunto por este construído mantinha melhor coerência lógica. Ademais, Grócio sistematicamente remetia as suas deduções, fundadas na reta razão, ao teste da efetividade da prática.

Embora a razão seja declarada como o teste supremo para a caracterização do conteúdo e dos efeitos do direito das gentes, Bynkershoek se insurge, contudo, contra a utilização arbitrária da assim chamada 'razão de estado' e a afasta, como fundamentação inadequada. ${ }^{105}$ Somente se pode concluir que a razão à qual sistematicamente alude não é outra se não a sua própria linha de argumentação.

Isso, de certa forma, conflita com o que assevera o próprio Bynkershoek, no sentido de todo argumento de autoridade, pouco importa de quem tenha emanado, não se revestirá de importância, se não for sancionado pela prática, pelo uso, pelo tácito consentimento das nações.

Em conclusão, o propósito deste breve ensaio, de conteúdo bastante esquemático, deve servir para suscitar o interesse e levar ao estudo direto das obras de Cornelius van Bynkershoek, para ensejar mais adequada avaliação da contribuição deste, para o desenvolvimento do Direito Internacional. Nenhum comentário substitui a leitura das obras dos mestres, de qualquer disciplina, e tampouco no caso do Direito Internacional.

Muitas vezes se passa demasiadamente rápido pelo exame da vida e da obra de Cornelius van Bynkershoek. Entre os primeiros 'pais' do Direito Internacional, sobretudo Vitória e Suarez, e logo mais os vultos imponentes das figuras de Grócio e Pufendorf, até os mestres mais recentes, que nô-lo trazem até o final do século XVIII e início do XIX, como Vattel e von Martens, parece tender a ficar menos em evidência a figura e a contribuição relevante deste internacionalista.

A contribuição de Cornelius van Bynkershoek se inscreve no tempo histórico e no contexto cultural no qual foi pensada e escrita. A fundamentação do Direito Internacional, tal como proposta por este, constitui lição de pragmatismo responsável:

\footnotetext{
${ }^{103}$ Id. Ibid. (livro I, cap. XV).

104 Id. Ibid. (livro I, caps. VIII, XII e XIII).

105 BYNKERSHOEK, C. van. Quaestiones juris publici libri duo (livro I, cap. XXIV).
} 
este tem origem em acordos tacitamente aceitos e pressupostos, fundados na razão e no uso. ${ }^{106}$ Não se põe fundamentação transcendente, nem a pretensão de conhecimento dos arcanos do Direito Natural, mas se impõe como ditame regulador da convivência entre soberanos. Aos particulares, rege as relações o Direito Civil e aos soberanos, a boa-fé e esta, como o Direito Internacional tem o seu papel a cumprir e devem ser observadas, para manter a possibilidade de relações entre os soberanos, dada a sua condição de iguais em direitos e independentes, em relação aos quais não existe nem poder superior, nem árbitro competente. Quanta tinta e quantos esforços se despenderam nessa busca infindável de fundamentos, para possível sistema institucional e normativo internacional.

A formulação de Bynkershoek, como o fez em relação aos limites do mar territorial, tem a felicidade da fórmula simples, cujo conteúdo se mostra apto a encontrar acolhida na realidade : fidem pactorum esse servanda. E se aceita por sua convicção de adequação, como de juridicidade.

Responde Bynkershoek a questões prementes do seu tempo, algumas das quais passaram a estar estruturadas, e isso depois de tempo considerável. De certa forma, poder-se-ia ver como ecoa, séculos depois do De foro legatorum, a regulação dos agentes diplomáticos - que alcançaria patamar adequado de regulação com a Convenção de Viena sobre relações diplomáticas, de 1961, e também mediante a Convenção de Viena sobre relações consulares, de 1963, e, sobretudo, depois de inscrever-se Bynkershoek em controvérsia que já durava bem mais de cem anos, quando este intervém e escreve o seu De dominio maris dissertatio, a questão da natureza jurídica e da extensão da soberania sobre faixa costeira de mar, por meio das categorias, consolidadas pela Convenção das Nações Unidas sobre o direito do mar, de 1982. Outras questões, àquele tempo, como ainda hoje conturbadas, permanecem; todavia, pouco mais resolvidas, como a questão da guerra e dos limites do uso unilateral da força, não-obstante os avanços conceituais alcançados, no tocante à proscrição da guerra como meio legítimo de solução de controvérsias entre Estados e os limites ao uso unilateral da força, implantados no Direito Internacional vigente, sobretudo o capítulo VII, da Carta da ONU e a estrita delimitação material e temporal, mesmo para o uso de recurso unilateral extremo, como a legítima defesa, nos termos do art. 51 do mesmo diploma constitucional internacional. Indagava Bynkershoek na sua obra magna, Quaestiones juris publici libri duo e até hoje são postas questões sobre dados como a licitude de alistar soldados em país estrangeiro, como exemplo de questão tormentosa, que permanece atual e presente; porquanto, vimos casos nesse sentido

\footnotetext{
106 Id. Ibid. (liber II, caput X, cit.), adiante do trecho antes referido, enfatiza: “Assim os tratados têm de ser conservados de boa-fé (fidem pactorum esse servanda), sob pena de se destruir tudo o que é prontamente concedido, e mesmo aqueles que nada aprenderam exceto traição, e em tudo frustram as normas de boa-fé, por meio de incontáveis exceções. Se, contudo, acordo público deverá sempre e em toda parte, ser conservado como inviolável e observado é questão muito complexa".
} 
ocorrerem em relação a nacionais brasileiros inscritos nas forças armadas dos Estados Unidos da América, levados para combate nas invasões de Afeganistão e do Iraque. Enquanto o Brasil permanecia neutro e manifestava oficialmente posição contrária às referidas operações militares.

Em suma, o Direito Internacional ao tempo e também por influência da ação e da obra de Bynkershoek, como reflexo das exigências do seu tempo e do seu meio cultural, poder-se-ia dizer contribuem para que a nossa disciplina passe por progressiva profissionalização, no sentido de que, progressivamente, se lhe conferem os mecanismos conceituais e procedimentais, adequados para a sua consolidação, como ramo jurídico autônomo. A questão da fundamentação deste se torna cada vez mais laica e mais conceitualmente livre do ponto de partida, inicialmente estipulado pelos dois precursores, Vitória e Suarez.

Entre o Direito Internacional, do final do século XVII, tal como o herda Bynkershoek, daqueles que aponta e reconhece como os 'grandes mestres', Grócio e Pufendorf, ao Direito Internacional que existe, quando falece em meados do século XVIII, considerável avanço se tenha realizado. Quase contemporâneo seu, pouco mais jovem, será Vattel o marco da entrada do Direito Internacional em nova fase, da qual sairá, ainda mais estruturado, e revestido de dimensão histórica, quando terminar a atuação e a obra de von Martens, no primeiro quartel do século XIX.

São Paulo, outubro de 2008. 